\title{
Analysis of the stress (RYR1) gene and osteochondrosis in wild boars in Lithuania
}

\author{
RAMUTIS KLIMAS, ASTA KLIMIENĖ, ILONA MICEIKIENE்*, KRISTINA MORKŪNIENE்**
}

\author{
Klaipèda University, H. Manto 84, 92294 Klaipèda, Lithuania \\ *Alytus College, Studentu 17, 62256 Alytus, Lithuania \\ ** Lithuanian University of Health Sciences, Mickevičiaus 9, 44307 Kaunas, Lithuania
}

\section{Klimas R., Klimienè A., Miceikienè I., Morkūnienė K. \\ Analysis of the stress (RYR1) gene and osteochondrosis in wild boars in Lithuania}

Summary

The aim of the experiment was to determine the RYR1 genotype and to analyse the distribution of osteochondrosis (OC) in wild boars from different regions of Lithuania. Hair and bone samples were collected from wild boars of various sexes and ages that had been shot during hunting season. Genomic DNA was extracted from hair roots. The RYR1 gene was analysed with the PCR-RFLP method, using specific primers and restriction enzymes Alw211 and Hin61. Only one $C$ allele $(q=1.00)$ and CC genotype of the RYR1 gene were identified. Thus 138 genotyped wild boars were stress-resistant with both dominant alleles intact (no mutation). $\mathrm{OC}$ was measured by the cut surface of the distal femur and humerus. The prevalence of $\mathrm{OC}$ among the 34 wild boars tested was $20.6 \% .5$ animals $(14.7 \%)$ had OC lesions in the hind legs and 2 animals $(5.9 \%)$ had them in the front legs. OC affected leg joints more often in adult females (third-years and older), but this dependence was not significant $(p>0.05)$.

Keywords: wild boar, RYR1 gene, osteochondrosis

The species of wild boar (Sus scrofa L.), which is widespread in Europe, Asia and North Africa, includes about 27 subspecies (7). Lithuania is the habitat of the Central European wild boar (Sus scrofa scrofa). As the ancestor of the domestic pig, the wild boar can mate reciprocally with the pig to give prolific progeny (18), with both swine and wild boar carrying 38 chromosomes (35). However, these animals may have some hereditary defects or diseases, such as stress sensitivity and osteochondrosis. Thus far, studies of these disorders and their influencing genes have mostly been carried out on domestic pigs, with wild boars only recently receiving increased attention.

Chromosome 6 (SSC6) of the domestic pig and the wild boar contains the ryanodine receptor 1 (RYRI) gene, also known as the halothane $(H A L)$ gene or the calcium release channel (CRC) gene (12). Mutation in the RYRl gene (transition of nucleotide/allele $\mathrm{C}$ to nucleotide/allele $\mathrm{T}$ at position 1843 , which leads to the replacement of the amino acid arginine with cysteine at position 615) is associated with porcine stress syndrome (PSS), also known as malignant hyperthermia $(\mathrm{MH})$. PSS/MH is a monogenic autosomal recessive hereditary disorder that leads to changed membrane characteristics in skeletal muscle fibres, more specifically to an increased release of calcium ions from the sarcoplasmic reticulum as a response to different stress factors $(6,11,32)$. Individual animals with the $R Y R 1 \mathrm{C}$ and $\mathrm{T}$ alleles combination are divided into three genotypes: CC - dominant homozygotes (stress-resistant), CT - heterozygotes (stress-resistant carriers), and TT - recessive homozygotes (stress-susceptible). $R Y R 1 / \mathrm{CC}, R Y R 1 / \mathrm{CT}$ and $R Y R 1 / \mathrm{TT}$ allelic pairs were associated with the halothane genotypes NN, Nn and $\mathrm{nn}$, respectively (34). There have been several studies to determine the prevalence of the RYRI mutation in wild boars. Mostly wild boars with the $\mathrm{CC}$ genotype (stress-resistant) have been reported $(8,21,26,40)$, while only isolated cases of wild boars with CT and TT genotypes have been identified $(1,4)$. Investigations of the stress-susceptibility of domestic pigs in Lithuania have been carried out (16), but the results of analogous studies on wild boars in the same territory have not yet been published.

Osteochondrosis (OC) is a degenerative disease of bone and cartilage tissues that occurs not only in humans, but also in many species of domestic animals, such as pigs $(13,15,17,20,37,39)$, horses (24), cattle (31), dogs (3), cats (30), and poultry (14). OC in animals has been documented in various joints, but its severity can be vary. The incidence of OC is highest in the distal femur and humerus condyles, which leads 
to leg weakness and affects animal welfare and longevity $(27,37,38)$. Environmental conditions have an influence on the more intense development of $\mathrm{OC}$ in pigs, which are susceptible to this disease (10). Currently, there are several OC lesion evaluation methods: radiological examination of live animals, post-mortem examination of joints, and genome examination (20). Quantitative trait loci (QTL), associated with OC or leg weakness in different breeds of pigs, may be located on several chromosomes $(2,5,22,23,29,36)$. Thus $\mathrm{OC}$ is a polygenic hereditary disorder. Because OC is commonly found in domestic pigs, it is likely to also exist in wild boars. Wild boars roam freely, sometimes over large distances. Consequently, biomechanical forces on the joints may also contribute to the development of OC in wild boars. Examinations of OC in wild boars are few, however, and the prevalence of articular OC is reported to be low (9). Andersson-Eklund et al. (2) found QTL affecting OC on chromosomes 5, 13 and 15 in hybrids of wild boars and domestic pigs.

This paper presents the results of research on the $R Y R 1$ genotype and distribution of OC in wild boars from Lithuania.

\section{Material and methods}

The study was carried out over a period of five years (2009-2013). Hair (bristle) and bone samples were collected from both male and female wild boars of various ages in the north, south, east and central regions of Lithuania that were shot during the hunting season. All animal experiment procedures were carried out in compliance with Lithuanian animal care, management and use legislation No. 8-500 (State news, 28 November 1997, no. 108). No special permits from the Lithuanian State Food and Veterinary Service or Environmental Protection Agency were needed as African Swine Fever (ASF) did not reach Lithuania until 2014.

DNA extraction and genotyping. Plucked hair samples were collected from 138 wild boars (56 females and 82 males). Four to five hair roots of each animal were used for genomic DNA isolation. DNA analysis was carried out according to the procedure described by Miceikienè et al. (25), extracted using the Chelex purification method. All Polymerase chain reactions (PCR) were performed using Applied Biosystems' 2700 Thermal Cycler. The RYRI gene was analysed with the PCR-RFLP method, using RYR 1 forward 5'-GTG-CTG-GAT-GTC-CTG-TGT-TCC-CT- 3' (9.2 $\mathrm{pmol} / \mathrm{ml}$ ) (Interlux) and $R Y R 1$ reverse 5'-CTG-GTG-ACATAG-TTG-ATG-AGG-TTT-G-3' (7.3 pmol/ml) (Interlux) oligonucleotide primers (10 pmol for each reaction), $0.2 \mathrm{mM}$ dNTP, $50 \mathrm{mM} \mathrm{MgCl}, 10 \times$ Taq Buffer $\left(\mathrm{NH}_{4}\right) \mathrm{SO}_{4}$, $1 \mathrm{U}$ Taq DNA polymerase, BSA $(20 \mathrm{mg} / \mathrm{ml})$ (JSC Thermo Fisher Scientific Baltics, LT). PCR were completed under the following conditions: $94^{\circ} \mathrm{C}$ for $3 \mathrm{~min}$, followed by 31 cycles of $94^{\circ} \mathrm{C}$ for $15 \mathrm{~s}, 69^{\circ} \mathrm{C}$ for $15 \mathrm{~s}$ and $72^{\circ} \mathrm{C}$ for $35 \mathrm{~s}$, with a final extension at $72^{\circ} \mathrm{C}$ for $5 \mathrm{~min}$. After amplifica-

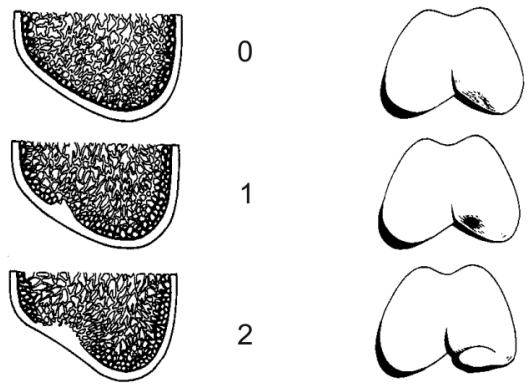

b

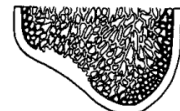

3
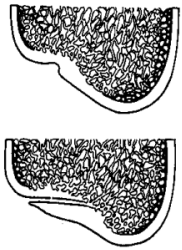

b

Fig. 1. Distal view of femoral and humeral condyles (a) and its cut surface (b) Explanations: 0 - smooth and rounded joint surface, normal thickness of cartilage regular cartilage-bone transition; 1 - smooth and rounded joint surface, cartiage; 2 - flattened joint surface, moderate retention of

tion, $10 \mu 1$ of the PCR amplification product was digested with Alw211 and Hin61 (JSC Grida, LT) $\left(7.5 \mu 1 \mathrm{dd} \mathrm{H} \mathrm{H}_{2} \mathrm{O}\right.$, $2 \mu 110 \times \mathrm{M}$ buffer, $0.5 \mu 1$ Alw211 or Hin61) restriction enzymes leaving it for $15 \mathrm{~h}$ at $37^{\circ} \mathrm{C}$. The point mutation is located in fragment $134 \mathrm{bp}$ in length, which is obtained after PCR. If the animal is stress-resistant (CC), restriction with Hin61 enzyme will produce 86 bp and 48 bp DNA fragments, and restriction with Alw211 enzyme will produce one $134 \mathrm{bp}$ fragment. Stress-resistant carriers (CT) will produce fragments $134 \mathrm{bp}, 86 \mathrm{bp}$ and $48 \mathrm{bp}$ with both restriction enzymes, while stress-susceptible animals with both alleles mutated (TT) have a recognition site for digestion with Alw211 (48 bp and 86 bp fragments) but do not have a recognition site for digestion with the Hin61 restriction enzyme (134 bp). Visualization of the different RYRI genotypes was obtained by $3 \%$ agarose gel electrophoresis at $100 \mathrm{~V}$ for $35 \mathrm{~min}$ after staining the gels with ethidium bromide for 15-20 min, using the "MiniBisPro" video documentation system (Herolab).

Osteochondrosis studies. After cutting the carcass of wild boars, OC was measured according to Reiland et al. (33) by the cut surface of the distal femur and humerus. The severity of this disease was scored in elbow and knee joints on a scale of $0-5$ points (Fig. 1). The scores range from 0 (no joint lesions) to 5 (severe joint lesions), with 1 indicating weak joint lesions. 34 wild boars of both sexes (19 females and 15 males) and a range of ages (14 second-years and 20 third-years or older) were tested. The age of the animals was determined visually and by the teeth method.

Statistical analysis. Descriptive statistics were processed using the SPSS program (version 20.0) for Windows. The frequency of alleles and genotypes at the RYR 1 locus within the investigated population of wild boars was calculated according to the Hardy-Weinberg law. The statistical significance of sex and age on OC lesions in wild boars was determined using Fisher's exact test.

\section{Results and discussion}

RYR1 gene. After electrophoresis, the gels were illuminated by UV rays and the $R Y R I$ genotype of wild boars were recorded. Restriction with the Hin61 enzyme produced $86 \mathrm{bp}$ and $48 \mathrm{bp}$ DNA fragment 


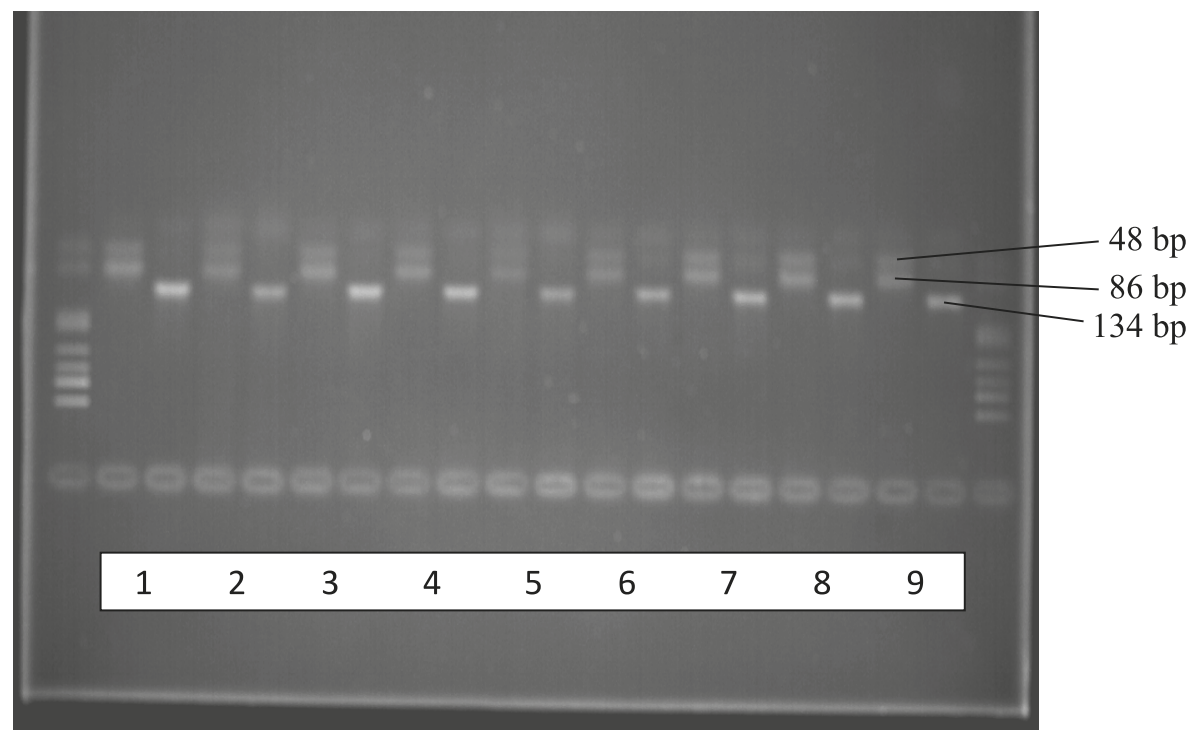

Fig. 2. Example for PCR product visible in agarose gel after electrophoresis (1 to 9 animals). One $C$ allele and $C C$ genotype of the $R Y R I$ gene were identified in all 138 wild boars

lengths and restriction with the Alw211 enzyme resulted in only one $134 \mathrm{bp}$ fragment. Consequently, all genotyped animals (Fig. 2) were stress-resistant with both alleles intact (CC, dominant homozygotes, no mutation).

Therefore, in domestic pigs and wild boars, the ryanodine receptor 1 gene mutation $(\mathrm{C}>\mathrm{T}$ transition, $R Y R 1 \mathrm{~T}$ ) is associated with stress susceptibility (PSS or $\mathrm{MH})$. Stress-susceptible swine have greater muscularity, yet worse reproduction and fattening traits and, in particular, poorer meat quality than stress-resistant animals $(16,19)$. Stress-sensitive animals, in comparison with their stress-resistant counterparts, have more difficultly surviving stressful situations, are worse at adapting to changing environmental conditions and are less healthy overall (34). In our study, all European wild boars $(\mathrm{n}=138)$ tested did not have the RYRI T allele (stress-resistant, no polymorphism). The monomorphic RYRl gene in these animals has also been established in other countries. Müller et al. (26) genotyped 10 European wild boars from Germany, Ernst et al. (8) genotyped 109 wild boars of two subspecies (Sus scrofa scrofa and Sus scrofa attila) from Germany and the Czech Republic, Kuryl et al. (21) genotyped 90 wild boars from northeast Poland, and Zinovieva et al. (40) genotyped 89 wild boars of different populations from Russia and reported only CC genotypes (wild type, no mutation). However, it was also reported that one of the European wild boars used for arrangement of the Nordic reference family for QTL mapping was a heterozygote (CT) at the $R Y R I$ locus (1). Borman et al. (4) reported that among the 29 genotyped wild boars from the Gdańsk forest district in Poland, there were $19(65 \%)$ stress-sensitive recessive homozygotes (TT), $8(28 \%)$ stress-resistant heterozygotes (CT) and only $2(7 \%)$ stress-resistant dominant homozygotes (CC) with both alleles intact. Consequently, all three genotypes are probably found at the RYRI locus among both wild boars and swine.

Osteochondrosis. The occurrence of OC among 34 wild boars tested was $20.6 \%$ (Tab. 1). This study indicated that females were more likely to have this disease than males $(26.3 \%$ vs. $13.4 \%, \mathrm{p}>0.05)$. Mild OC (one point) incidence was determined in the joints of the front and hind legs of most ( 5 cases) animals. Overall, there were 2 cases where OC severity reached 2 points (both in the knee joint of males). In addition, hind legs were more affected by joint lesions. $\mathrm{OC}$ scores of 3 to 5 points were not registered. When analysing OC severity in relation to age (Tab. 2), it was determined that $14.7 \%$ adult (third-years or older) and $5.9 \%$ young (second-years) wild boars have leg joint lesions. This tendency especially manifested itself for females (21.0\% and 5.3\%, respectively). However, the effect of age on OC in wild boars, as in the case of sex, was not significant.

In animals, the word $\mathrm{OC}$ is mostly restricted to focal necrotic lesions on growth cartilage, leading to focal impaired endochondral ossification of the articularepiphyseal cartilage complex (AECC). There is substantial evidence that $\mathrm{OC}$ in animals is initiated by ischemia of the growth cartilage, caused by the necrosis of vessels in cartilage canals, resulting in a disruption of the blood supply within the AECC $(28,38)$. In joints affected by OC, macroscopically-visible lesions are typically found, including the local thickening of articular cartilage, irregular cartilage surfaces, fissures between cartilage and subchondral bone, osteochondrosis dissecans (OCD), and necrosis of subchondral bone (38). OC deforms joints and reduces leg strength,

Tab. 1. Prevalence of osteochondrosis among investigated wild boars

\begin{tabular}{|c|c|c|c|c|c|c|c|c|c|c|c|c|c|}
\hline \multirow{3}{*}{$\begin{array}{c}\text { Sex } \\
\text { Females }\end{array}$} & \multirow{3}{*}{$\begin{array}{c}\begin{array}{c}\text { No. of } \\
\text { animals }\end{array} \\
19\end{array}$} & \multicolumn{2}{|c|}{ Joint lesions } & \multicolumn{3}{|c|}{ Lesion score in elbow joint } & \multicolumn{3}{|c|}{ Lesion score in knee joint } & \multicolumn{2}{|c|}{ Lesion score in both joint } & \multirow{2}{*}{\multicolumn{2}{|c|}{$\mathrm{p}$ value }} \\
\hline & & No. & $\%$ & $\begin{array}{c}1 \\
\text { (No.) }\end{array}$ & $\begin{array}{c}2 \\
\text { (No.) }\end{array}$ & $\begin{array}{c}3-5 \\
\text { (No.) }\end{array}$ & $\begin{array}{c}1 \\
\text { (No.) }\end{array}$ & $\begin{array}{c}2 \\
\text { (No.) }\end{array}$ & $\begin{array}{c}3-5 \\
\text { (No.) }\end{array}$ & $\begin{array}{c}1-2 \\
\text { (No.) }\end{array}$ & $\begin{array}{c}3-5 \\
\text { (No.) }\end{array}$ & & \\
\hline & & 5 & 26.3 & 2 & - & - & 3 & - & - & - & - & \multirow{2}{*}{0.426} & \multirow{2}{*}{ ns } \\
\hline Males & 15 & 2 & 13.4 & - & - & - & - & 2 & - & - & - & & \\
\hline Total & 34 & 7 & 20.6 & 2 & - & - & 3 & 2 & - & - & - & $x$ & $x$ \\
\hline
\end{tabular}

Explanation: ns - effect of sex on OC was not significant $(\mathrm{p}>0.05)$ 
Tab. 2. Distribution by age of wild boar females and males having normal joints (0 score) and osteochondrotic joint lesions

\begin{tabular}{|c|c|c|c|c|c|c|c|c|c|}
\hline \multirow[t]{2}{*}{ Sex } & \multirow[t]{2}{*}{ Age } & \multicolumn{2}{|c|}{$\begin{array}{l}\text { Investigated } \\
\text { animals }\end{array}$} & \multicolumn{2}{|c|}{ Normal joint } & \multicolumn{2}{|c|}{ Joint lesions } & \multirow{2}{*}{\multicolumn{2}{|c|}{$\mathrm{p}$ value }} \\
\hline & & No. & $\%$ & No. & $\%$ & No. & $\%$ & & \\
\hline \multirow{3}{*}{ Females } & Second-years & 7 & 36.9 & 6 & 31.6 & 1 & 5.3 & \multirow{3}{*}{$\begin{array}{c}0.603 \\
x\end{array}$} & \multirow{2}{*}{ ns } \\
\hline & Third-years and older & 12 & 63.1 & 8 & 42.1 & 4 & 21.0 & & \\
\hline & Total & 19 & 100.0 & 14 & 73.7 & 5 & 26.3 & & $\mathbf{x}$ \\
\hline \multirow{3}{*}{ Males } & Second-years & 7 & 46.7 & 6 & 40.0 & 1 & 6.7 & \multirow{2}{*}{1.000} & \multirow{2}{*}{ ns } \\
\hline & Third-years and older & 8 & 53.3 & 7 & 46.6 & 1 & 6.7 & & \\
\hline & Total & 15 & 100.0 & 13 & 86.6 & 2 & 13.4 & $\mathbf{x}$ & $\mathbf{x}$ \\
\hline \multirow{3}{*}{ Total } & Second-years & 14 & 41.2 & 12 & 35.3 & 2 & 5.9 & \multirow{2}{*}{0.672} & \multirow{2}{*}{ ns } \\
\hline & Third-years and older & 20 & 58.8 & 15 & 44.1 & 5 & 14.7 & & \\
\hline & Total & 34 & 100.0 & 27 & 79.4 & 7 & 20.6 & $x$ & $\mathbf{x}$ \\
\hline
\end{tabular}

Explanation: ns - effect of age on OC was not significant $(p>0.05)$

the animals were found to have no significant effect on OC $(\mathrm{p}>0.05)$. Because wild boars roam, have natural predators and are hunted, it is probable that selection pressure may have favoured those that are well adapted to an active life thanks to healthy joint structures and the stress-resistant genotype. resulting in animals which start limping, unable to walk properly $(27,37)$. The aetiology of OC is multifactorial, including genetic (heredity) and environmental factors, rapid growth rates, high muscularity, anatomical characteristics, and biomechanical forces $(15,28,38)$. The prevalence of osteochondrotic joint lesions in animals varies not only due to etiological factors, but also due to the OC diagnosis method used $(9,13)$.

Various studies have shown that between $35-100 \%$ of pigs are eliminated from breeding programmes because of leg weakness (20). In Lithuania, the occurrence of OC among all tested pigs $(\mathrm{n}=1596)$ of various breeds was $47.4 \%$ (17). Thus OC is a common disease in domestic pigs. Examinations of OC in wild boars, on the other hand, are rare. Etterlin (9) used computed tomography to conduct post-mortem scans of the hock joints (hind legs) of 39 wild boars from Sweden and reported that five animals (13\%) had OC on the talus. In our study, 34 wild boars were tested in total, 7 of which $(20.6 \%)$ had OC lesions: 2 animals in the front legs and 5 in the hind legs. In comparison with swine, the prevalence of articular OC among wild boars is low. According to the study data, OC affected leg joints more often in adult females (third-years and older), though this dependence was not significant. No literature data was found on the prevalence and severity of OC in relation to the sex and age of wild boars. OC is subsequently considered to be a risk to the welfare and longevity of animals (37), since leg weakness (lameness) restricts migration and shortens the life span and effective reproductive age in wild boars. Such wild boars (with OC lesions) have more difficulty finding food, especially during the winter.

The results of this study demonstrate that one allele $\mathrm{C}(\mathrm{q}=1.00)$ and one CC genotype of the RYRI gene were identified in wild boars. Therefore, all genotyped animals were stress-resistant with both dominant alleles intact (no mutation). Another situation was fixed while testing OC. The prevalence of OC among all tested wild boars was $20.6 \%$. However, the sex and age of

\section{References}

1. Andersson-Eklund L., Marklund L., Lundström K., Halfy C. S., Andersson K., Hanson I., Moller M., Andersson L.: Mapping quantitative trait loci for carcass and meat quality traits in a Wild boar x Large White intercross. J. Anim. Sci. 1998, 76, 694-700.

2.Andersson-Eklund L., Uhlhorn H., Lundeheim N., Dalin G.: Mapping quantitative trait loci for principal components of bone measurements and osteochondrosis scores in a wild boar $\times$ Large White intercross. Genet. Res. 2000, 75, 223-230.

3. Biežynski J., Skrzypczak P., Piatek A., Kosciolek N., Droždžynska M.: Assessment of treatment of osteochondrosis dissecans (OCD) of shoulder joint in dogs - the results of two years of experience. Pol. J. Vet. Sci. 2012, 15, 285-290.

4. Borman A., Stojek W., Kwaczynska A., Schultka R., Leszkowicz E., KamyczekM., Glac W., Ciepielewski Z., Kloss G., Tokarski J., Swiergiel A. H.: Unexpected high frequency of the stress - susceptibility conferring RYR1 T allele in a city forest wild boar population. Anim. Sci. Pap. Rep. 2016, 34, 405-410.

5. Christensen O. F., Busch M. E., Gregersen V. R., Lund M. S., Nielsen B., Vingborg R. K. K., Bendixen C.: Quantitative trait loci analysis of osteochondrosis traits in the elbow joint of pigs. Animal 2010, 4, 417-424.

6. Dietze B., Henke J., Eichinger H. M., Lehmann-Horn F., Melzer W.: Malignant hyperthermia mutation $\mathrm{Arg} 615 \mathrm{Cys}$ in the porcine ryanodine receptor alters voltage dependence of $\mathrm{Ca} 2+$ release. J. Physiol. 2000, 526, 507-514.

7. Epstein H.: Pig, [in:] Mason I. L. (ed.): Evolution of domesticated animals. Longman, London 1984, p. 145-162.

8. Ernst M., Kuciel J., Urban T.: Analysis of genetic variation of eight candidate genes in two wild boar subspecies. Czech. J. Anim. Sci. 2003, 48, 533-539.

9. Etterlin P. E.: Osteochondrosis in domestic pigs and wild boars. Osteochondrosis in pigs: A study of the effects of free - range housing in a herd of fattening pigs. Doctoral thesis, Swedish University of Agricultural Sciences, Uppsala 2016, p. 37-44.

10. Fukawa K., Kusuhara S.: The genetic and non - genetic aspects of leg weakness and osteochondrosis in pig - review. Asian Australas. J. Anim. Sci. 2001, 14, 114-122.

11. Fujii J., Otsu K., Zorzato F., Leon S., Khanna V. K., Weiler J. E., O'Brien P. J., Maclennan $D$. H.: Identification of mutation in porcine ryanodine receptor associated with malignant hyperthermia. Science 1991, 253, 448-451.

12. Groenen M. A. M., Schook L. B., Archibald A. L.: Pig genomics, [in:] Rothchild M. F., Ruvinsky A. (eds.): The genetics of the pig. $2^{\text {nd }}$ ed. CAB International, Wallingford, Oxfordshire 2011, p. 179-199.

13. Jorgensen B., Andersen S.: Genetic parameters for osteochondrosis in Danish Landrace and Yorkshire boars and correlation with leg weakness and production traits. J. Anim. Sci. 2000, 71, 427-434.

14. Julian R. J.: Rapid growth problems: Ascites and skeletal deformities in broilers. Poultry Sci. 1998, 77, 1773-1780.

15. Kadarmideen H. N., Schwörer D., Ilahi H., Malek M., Hafer A.: Genetics of osteochondral disease and its relationship with meat quality and quantity growth, and feed conversion traits in pigs. J. Anim. Sci. 2004, 82, 3118-3127.

16. Klimas R., Klimiene A.: Performance of pigs of different halothane phenotypes. Animal Husbandry: Scientific Articles 2002, 40, 24-31 (In Lithuanian, abstract in English and Russian). 
17. Klimiene A., Klimas R.: Pig osteochondrosis in Lithuania: prevalence, influence on productivity, selection vista. Med. Weter. 2006, 62, 152-155.

18. Klimiene A., Klimas R.: The influence of the wild boar on the biological and performance traits of domestic pigs. Pol. J. Nat. Sci. 2010, 25, 123-131.

19. Kortz J., Kapelanski W., Grajewska S., Kuryl J., Bocian M., RybarczykA.: Meat quantity to meat quality relationships when the RYR1 gene effect is eliminated, [in:] Wenk C., Fernandez J. A., Dupuis M. (eds.): Quality of meat and fat in pigs as affected by genetics and nutrition. Wageningen 2000, p. 143-146.

20. Korwin-Kossakowska A., Sender G., Sartowska K., Lewczuk D.: Genetics of swine osteochondrosis: a review. Med. Weter. 2013, 69, 515-520.

21. Kuryl J., Zurkowski M., Urbanski P., Wyszynska-Koko J.: Distribution of the polymorphic variants of genes RYR1, LEP, GH, MYOG, MYF5, and GDF8 in wild boars from North - East of Poland. Anim. Sci. Pap. Rep. 2004, 22, 271-278.

22.Laenoi W., Uddin M. J., Cinar M. U., Große-Brinkhous Ch., Tesfaye D., Jonas E., Scholz A. M., Tholen E., Looft Ch., Wimmers K., Phatsara Ch., Juengst H., Sauerwein H., Mielenz M., Schellander K.: Quantitative trait loci analysis for leg weakness - related traits in Duroc $\times$ Pietrain crossbred population. Genet. Sel. Evol. 2011, 43, 13. Doi: 10.1186/1297-9686-43-13.

23. Lee G. J., Archibald A. L., Garth G. B., Law A. S., Nicholson D., Barr A., Haley C. $S$.: Detection of quantitative trail loci for locomotion and osteochondrosis related traits in Large White $\times$ Meishan pigs. J. Anim. Sci. 2003, 76, 155-165.

24. Lewczuk D., Korwin-Kossakowska A.: Genetic background of osteochondrosis in the horse - a review. Anim. Sci. Pap. Rep. 2012, 30, 205-218

25. Miceikienè I., Paulauskas A., Grigaliūnaitè I., Malevičiūtè J., Tubelyté Kirdiene $V$ : Genetics practicum. Research methods of DNA polymorphism. Kaunas 2002, 1-72. (In Lithuanian).

26. Müller E., Moser G., Bartenschlager H., Geldermann H.: Trait values of growth, carcass and meat quality in Wild boar, Meishan and Pietrain pigs as well as their crossbred generations. J. Anim. Breed. Genet. 2000, 117, 189-202.

27. Olsson S. E.: Osteochondrosis in domestic animals. Acta Radiol. Suppl. 1978 358, 9-14.

28. Olstad K., Ekman S., Carlson C. S.: An update on the pathogenesis of osteochondrosis. Vet. Pathol. 2015, 52, 785-802.

29. Onteru S. K., Fan B., Mote B., Serenius T., Nikkilae M., Stalder K. J., Rothschild $M$. F.: SNP discovery in genes affecting leg health traits in pigs. Dev. Biol. $2008,132,337-342$
30. Palierne S., Palissier F., Raymond-Letron I., Autefage A.: A case of bilateral patellar osteochondrosis and fracture in a cat. Clinical and histological findings. Vet. Comp. Orthopaed. 2010, 23, 128-133.

31. Persson Y., Söderquist L., Ekman S.: Joint disorder a contributory cause to reproductive failure in beef bulls. Acta Vet. Scand. 2007, 49, 31. Doi: 10.1186/1751-0147-49-31.

32. Reggiani C., Kronnie T.: RYR isoforms and fibre type - specific expression of proteins controlling intracellular calcium concentration in skeletal muscles. J. Muscle Res. Cell M. 2006, 27, 327-335.

33. Reiland S., Ordell N., Lundeheim N., Olsson S. E.: Heredity of osteochondrosis, body constitution and leg weakness in the pig. Acta Radiol. Suppl. 1978, 358, 123-137.

34. Rejduch B.: Genes associated with production and health in farm animals. Journal Central European Agriculture 2008, 9, 829-836.

35. Ruvinsky A., Rothschild M. F., Larson G., Gongora J.: Systematics and evolution of the pig, [in:] Rothschild M. F., Ruvinsky A. (eds.): The genetics of the pig. $2^{\text {nd }}$ ed. CAB International, Wallingford, Oxfordshire 2011, p. 1-13.

36. Uemoto Y., Sato S., Ohnishi C., Hirose K., Kameyama K., Fukawa K., Kudo O., Kobayashi E.: Quantitative trait loci for leg weakness traits in a Landrace purebred population. J. Anim. Sci. 2010, 81, 28-33.

37. Yazdi M. H., Lundeheim N., Rydhmer L., Ringmar-Cederberg L., Johansson K. Survival of Swedish Landrace and Yorkshire sows in relation to osteochondrosis: a genetic study. J. Anim. Sci. 2000, 71, 1-9.

38. Ytrehus B., Carlson C. S., Ekman S.: Etiology and pathogenesis of osteochondrosis. Vet. Pathol. 2007, 44, 429-448.

39. Ytrehus B., Grindflek E., Teige J., Stubsjoen E., Grondalen T., Carlson C. S., Ekman $S$.: The effect of parentage on the prevalence, severity and location of lesions of osteochondrosis in swine. J. Vet. Med. A. 2004, 51, 188-195.

40. Zinovieva N. A., Kostyunina O. V., Ekonomov A. V., Shevnina M. S., Domskij I. A., Gladyr E. A., Brem G.: Polymorphism of genes associated with the quantitative trait loci in wild boar (Sus scrofa L., 1758) in Russia. Agricultural Biology 2013, 2, 77-82.

Corresponding author: Prof. hab. dr. Ramutis Klimas, Faculty of Health Sciences, Klaipėda University, H. Manto 84, 92294 Klaipėda, Lithuania; e-mail: klimas.ramutis@gmail.com 